\title{
Pengaruh Kemampuan Teknik Pemakai pada Kinerja Individual dengan Efektivitas Sistem Informasi Akuntansi Sebagai Variabel Pemoderasi
}

\author{
I Kadek Bagus Acintiawan ${ }^{1}$ \\ Fakultas Ekonomi dan Bisnis \\ Universitas Udayana, Indonesia. \\ Email: bagusacintiawan@gmail.com
}

\author{
Ida Bagus Putra Astika ${ }^{2}$ \\ Fakultas Ekonomi dan Bisnis \\ Universitas Udayana, Indonesia.
}

\begin{abstract}
ABSTRAK
Agar penerapan SIA berjalan dengan efektif diperlukan kemampuan teknik pemakai yang tinggi yang tentunya dapat meningkatkan kinerja individual dari pemakai tersebut. Penelitian ini menggunakan metode kuantitatif berbentuk asosiatif. Teknik analisis data yang digunakan dalam penelitian ini adalah analisis Moderated Regression Analysis (MRA). Hasil penelitian ini menunjukkan bahwa kemampuan teknik pemakai mempunyai pengaruh positif pada kinerja individual di Koperasi Simpan Pinjam di Kabupaten Badung dan efektivitas Sistem Informasi Akuntansi memoderasi pengaruh kemampuan teknik pemakai pada kinerja individual di Koperasi Simpan Pinjam di Kabupaten Badung. Implikasi dalam penelitian ini adalah semakin tinggi kemampuan teknik pemakai, maka semakin tinggi kinerja individual dan Semakin baik kemampuan teknik pemakai maka akan meningkatkan efektivitas Sistem Informasi Akuntansi sehingga kinerja individual akan meningkat.
\end{abstract}

Kata Kunci : $\quad$ Sistem Informasi Akuntansi; Kemampuan Teknik Pemakai; Kinerja Individual.

\section{Effect of User Technical Capabilities on Individual Performance with the Effectiveness of Accounting Information Systems as a Moderating Variable}

\begin{abstract}
In order for the implementation of SIA to run effectively it requires a high level of user engineering capability which can certainly improve the individual performance of these users. This study uses an associative quantitative method. The data analysis technique used in this study is the analysis of Moderated Regression Analysis (MRA). The results of this study indicate that user technical abilities have a positive influence on individual performance in Savings and Loan Cooperatives in Badung Regency and the effectiveness of the Accounting Information System moderates the influence of user technical abilities on individual performance in Savings and Credit Cooperatives in Badung Regency. The implication in this study is that the higher the ability of the user technique, the higher the individual performance and the better the ability of the user technique will increase the effectiveness of the Accounting Information System so that individual performance will increase.
\end{abstract}

Keywords: Accounting Information Systems; User Technical Capabilities; Individual Performance.

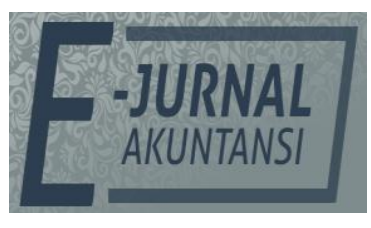

E-JA

e-Jurnal Akuntansi e-ISSN 2302-8556

Vol.298 No. 1

Denpasar, Oktober

2019

Hal. 451-467

Artikel masuk:

14 Agustus 2019

Tanggal diterima: 19 September 2019 


\section{PENDAHULUAN}

Penggunaan teknologi informasi di era sekarang ini merupakan elemen penting dalam aktivitas perusahaan. Sistem informasi membawa pengaruh besar terhadap hampir semua aspek dalam pengelolaan bisnis, termasuk dalam pengelolaan lembaga keuangan perbankan dan non perbankan termasuk koperasi. Perkembangan sebuah sistem informasi juga perlu didukung oleh banyak faktor yang diharapkan bisa memberikan keberhasilan dari sistem tersebut. Keberhasilan aplikasi sistem informasi pada suatu perusahaan dipengaruhi dari jenis pemanfaatan teknologi yang digunakan, cara sistem itu dijalankan, tingkat kemudahan sistem itu bagi para pemakainya, dan kemampuan teknik pemakai dalam menjalankan teknologi yang digunakan (Grande, 2011).

Penelitian ini didorong oleh fenomena perkembangan Koperasi Simpan Pinjam (KSP) di Kabupaten Badung yang semakin meningkat. Kondisi perkembangan teknologi yang semakin berkembang sebagaimana dikemukakan di atas menuntut lembaga KSP untuk dapat memanfaatkan dukungan teknologi informasi dalam operasional usahanya. Kondisi persaingan yang kompetitif menuntut KSP di Kabupaten Badung untuk menunjukan keunggulannya. Salah satu hal yang berperan dalam menunjukan keunggulannya, yaitu dengan penggunaan Sistem Informasi Akuntansi (SIA) dengan program aplikasi agar mampu menghasilkan informasi akuntansi yang berkualitas sehingga mendukung proses pengambilan keputusan yang tepat dan dapat meningkatkan pelayanan kepada anggota. Permasalahan yang dihadapi KSP di Kabupaten Badung yang telah menerapkan teknologi informasi tidak serta merta meningkatkan kinerjanya. Kinerja sistem informasi yang baik tidak selalu bisa meningkatkan kinerja koperasi. Namun sebagian besar koperasi simpan pinjam di Kabupaten Badung mengakui bahwa penerapan sistem teknologi informasi membantu meningkatkan kinerja perusahaan. Agar penerapan SIA dapat berjalan dengan efektif diperlukan kemampuan teknik pemakai yang tinggi yang tentunya dapat meningkatkan kinerja individual dari pemakai tersebut. Fenomena inilah yang menjadi alasan dilakukan penelitian mengenai pengaruh kemampuan teknik pemakai pada kinerja individual dengan efektivitas sistem informasi akuntansi sebagai variabel pemoderasi KSP di Kabupaten Badung.

Kinerja yang baik dapat terlihat apabila individu dapat menyelesaikan dan melaksanakan tugasnya dengan baik. Individu diharapkan dapat menyelesaikan pekerjaannya dengan bantuan teknologi, sehingga tugas yang dikerjakan dapat diselesaikan (Alannita \& Suaryana, 2014). Kinerja lebih tinggi berarti terjadi peningkatan kualitas yang baik dari kinerja individu, sehingga tugas yang akan diberikan kepada individu dalam suatu organisasi dapat dilaksanakan dengan tepat waktu (Murty \& Hudiwinarsih, 2012). Amelia \& Puspitawati, (2011) menyatakan bahwa teknologi informasi dapat dimanfaatkan secara efektif sehingga dapat memberikan kontribusi terhadap kinerja individual. Kinerja bergantung pada kombinasi antara kemampuan, usaha, dan kesempatan yang diperoleh. Adanya Sistem Informasi Akuntansi memudahkan karyawan untuk melakukan pekerjaannya sehingga kinerja karyawan semakin baik. Pihak manajemen dapat mengukur kinerja karyawan dari kualitas kerjanya berdasarkan kinerja dari masing-masing karyawan. 
Kemampuan teknik pemakai Sistem Informasi Akuntansi banyak memberikan dampak positif bagi perusahaan dan dunia bisnis. Penerapan suatu sistem memberikan dua dampak bagi perusahaan yaitu keberhasilan sistem dan kegagalan sistem. Baik buruknya kinerja dari sebuah sistem informasi dapat dilihat dari kepuasan pemakai Sistem Informasi Akuntansi tersebut. Para pemakai menjadi fokus yang penting dalam penerapan sebuah sistem dalam perusahaan. Pemakai atau pengguna merupakan suatu hal yang tidak terlepas dari penerapan teknologi, selain itu keberadaan manusia sangat berperan penting dalam penerapan teknologi. Ariyanto, (2013) menyatakan bahwa penggunaan teknologi sistem informasi yang tepat didukung oleh keahlian personel untuk mengoperasikan dan dapat meningkatkan kinerja perusahaan maupun kinerja individual pada perusahaan. Alannita \& Suaryana, (2014) menyatakan bahwa kemampuan teknik pemakai Sistem Informasi Akuntansi berpengaruh positif terhadap kinerja individu unit simpan pinjam koperasi.

Menurutnya Technology Acceptance Model (TAM) yaitu sebuah model untuk menjelaskan dan memprediksi penerimaan pengguna terhadap suatu teknologi berdasarkan pengaruh dua faktor, yaitu persepsi kemanfaatan (perceived usefulness) dan persepsi kemudahan penggunaan (perceived ease of use) (Jogiyanto, 2012). Hal ini juga didukung oleh Jogiyanto, (2012) yaitu menjelaskan bahwa TAM berfokus pada sikap terhadap pemakaian teknologi informasi, dimana pemakai mengembangkan berdasarkan persepsi manfaat dan kemudahan dalam penggunaan teknologi informasi.

TAM meyakini bahwa penggunaan sistem informasi akan meningkatkan kinerja individu atau organisasi (Gupta, 2011). Tujuan utama TAM adalah untuk memberikan dasar penelusaran dari pengaruh faktor eksternal terhadap kepercayaan, sikap dan tujuan pengguna. TAM menyediakan suatu basis teoritis untuk mengetahui faktor-faktor yang mempengaruhi penerimaan terhadap suatu teknologi dalam suatu organisasi. TAM menjelaskan hubungan sebab akibat antara keyakinan (akan manfaat suatu sistem informasi dan kemudahan penggunaannya) dan perilaku, tujuan/keperluan, dan penggunaan aktual dari pengguna/user suatu sistem informasi (Nugroho, 2014). TAM menawarkan suatu penjelasan yang kuat dan efisien untuk dapat menguji perilaku penerimaan dan penggunaan Sistem Informasi (SI) oleh pemakai. Dalam TAM, penerimaan pemakai SI ditentukan oleh dua faktor kunci yaitu perceived usefulness dan perceived ease of use. Dua faktor tersebut memberikan gambaran bahwa apabila SI mudah digunakan dan bermanfaat, maka pemakai akan cenderung untuk menggunakan SI tersebut.

Model TAM yang dikembangkan dari teori psikologis, menjelaskan perilaku pengguna komputer yaitu berlandaskan pada kepercayaan (belief), sikap (attitude), keinginan (intention), dan hubungan perilaku pengguna (user behaviour relationship). Tujuan model ini adalah untuk menjelaskan faktor-faktor utama dari perilaku pengguna terhadap penerimaan pengguna teknologi. Secara lebih terinci menjelaskan tentang penerimaan Teknologi Informasi (TI) dengan dimensi-dimensi tertentu yang dapat mempengaruhi diterimanya TI oleh pengguna (user).

Sistem Informasi Akuntansi memperlancar pekerjaan karena mereka menghubungkan informasi dari bagian atas dan bawah yang membantu para 
pekerja di perusahaan-perusahaan untuk mencapai tujuan mereka (Ismail \& King, 2014). Marlinawati \& Suaryana, (2012) menyatakan bahwa efektivitas Sistem Informasi Akuntansi berpengaruh secara signifikan terhadap kinerja individual.

Hasil penelitian Mahendra \& Widhiyani, (2016) menunjukkan kemampuan teknik pemakai memoderasi pengaruh efektivitas sistem informasi akuntansi pada kinerja individual. Penelitian Suartika \& Widhiyani, (2017) menemukan bahwa kemampuan teknik personal berpengaruh positif pada efektivitas penggunaan sistem informasi akuntansi, pendidikan dan pelatihan memperkuat pengaruh kemampuan teknik personal pada efektivitas penggunaan sistem informasi akuntansi. Selanjutnya hasil penelitian Widyasari \& Suardikha, (2015) menyimpulkan kemampuan teknik pemakai sistem informasi akuntansi, efektivitas sistem informasi akuntansi, dukungan manajemen puncak, dan lingkungan kerja fisik berpengaruh positif pada kinerja individual.

Kemampuan teknik menunjuk pada kepastian individu untuk mengerjakan berbagai tugas dalam pekerjaan tertentu. Kemampuan untuk melakukan fungsi pekerjaan sambil menerapkan/menggunakan pengetahuan penting. Kemampuan yang dibuktikan melalui kegiatan/perilaku yang diperlukan untuk melakukan pekerjaan (Robbins \& Judge, 2013). Sementara menurut Susanto, (2013) kemampuan teknik pemakai SIA yaitu suatu kapasitas pemakai untuk mengerjakan berbagai tugas dalam pendekatan bagaimana menggunakan alat-alat dan peraturan-peraturan yang melengkapi satu atau lebih tahapan-tahapan dalam siklus pengembangan sistem informasi akuntansi.

Penelitian Alannita \& Suaryana, (2014) menemukan bukti bahwa kemampuan teknik pemakai berpengaruh positif terhadap kinerja individu. Teori keyakinan diri menjelaskan proses kognitif sebagai salah satu proses keyakinan diri yang mempengaruhi fungsi manusia (Bandura, 2010). Proses tersebut meliputi kemampuan individu dalam menganalisis dan mengungkapkan ide. Kemampuan yang dimiliki oleh karyawan akan meningkatkan keyakinan diri yang mempengaruhi penggunaan sistem informasi. Kemampuan pengoperasian sistem seorang pemakai sangat dibutuhkan. Penggunaan Sistem Informasi Akuntansi dalam organisasi menuntut pemakai komputer (user) meningkatkan kemampuannya dalam menggunakan komputer (Mahendra \& Widhiyani, 2016). Pemakai yang mahir dan memahami sistem akan berpengaruh pada kinerja yang dihasilkan dari sistem tersebut. Berdasarkan uraian tersebut, maka disusun hipotesis sebagai berikut:

$\mathrm{H}_{1}$ : Kemampuan teknik pemakai berpengaruh positif dan signifikan pada kinerja individual di Koperasi Simpan Pinjam di Kabupaten Badung.

Model yang disebut TAM mendeskripsikan terdapat dua faktor yang secara dominan mempengaruhi integrasi teknologi (Wijaya \& Aliyanto, 2015). Faktor pertama adalah persepsi pengguna terhadap manfaat teknologi. Sedangkan faktor kedua adalah persepsi pengguna terhadap kemudahan penggunaan teknologi. Kedua faktor tersebut mempengaruhi kemauan untuk memanfaatkan teknologi. Selanjutnya kemauan untuk memanfaatkan teknologi akan mempengaruhi penggunanan teknologi yang sesungguhnya. 
Pemakai Sistem Informasi Akuntansi berperan penting dalam kemajuan suatu perusahaan. Pemakai Sistem Informasi Akuntansi dapat mendorong kinerja sistem informasi menjadi lebih baik. Kinerja sistem informasi berjalan dengan baik apabila para pemakai dapat memahami, menggunakan, dan mengaplikasikan sebuah teknologi menjadi sebuah informasi yang berguna untuk pengambilan keputusan sehingga tujuan perusahaan dapat terpenuhi dan kinerja individual dapat dinilai baik. Kemampuan teknik personal pemakai sistem informasi berperan penting dalam mengembangkan sistem informasi untuk dapat menghasilkan informasi guna menciptakan laporan perencanaan yang akurat, oleh karena itu setiap karyawan harus dapat menguasai penggunaan sistem berbasis komputer agar dapat memproses sejumlah transaksi dengan cepat dan terintegrasi, dapat menyimpan data dan mengambil data dalam jumlah yang besar, dapat mengurangi kesalahan matematik, menghasilkan laporan tepat waktu dalam berbagai bentuk, serta dapat menjadi alat bantu keputusan (Setyawan, 2013).

Keahlian pemakai komputer dan kenyamanan fisik tidak mampu meningkatkan pengaruh tingkat efektivitas Sistem Informasi Akuntansi terhadap kinerja karyawan (Pratama \& Suardikha, 2013). Alannita \& Suaryana, (2014) menyatakan bahwa kemampuan teknik pemakai Sistem Informasi Akuntansi berpengaruh positif terhadap kinerja individu. Widyasari \& Suardikha, (2015) menyatakan bahwa kemampuan pemakai Sistem Informasi Akuntansi berpengaruh positif terhadap kinerja individual. Berdasarkan uraian tersebut, maka disusun hipotesis sebagai berikut:

$\mathrm{H}_{2}$ : Efektivitas Sistem Informasi Akuntansi mampu memoderasi pengaruh kemampuan teknik pemakai pada kinerja individual di Koperasi Simpan Pinjam di Kabupaten Badung.

Model teknologi yang disebut TAM merupakan salah satu teori adaptasi dari Theory of Reasoned Action (TRA) yang sebelumnya telah diperkenalkan oleh Ajzen dan Fishbein pada tahun 1980 dan diusulkan oleh Davis pada tahun 1989. TRA merupakan sebuah teori yang menjelaskan sebuah perilaku dilakukan karena individu mempunyai kemauan atau niat untuk melakukan terkait kegiatan yang akan dilakukan atas kemauan sendiri. TAM menjelaskan suatu hubungan sebab akibat antara suatu keyakinan (manfaat suatu sistem informasi dan kemudahan penggunaannya) serta perilaku, keperluan dan pengguna suatu sistem informasi.

TAM berfokus pada sikap terhadap pemakai teknologi informasi, di mana pemakai mengembangkannya berdasarkan persepsi manfaat dan kemudahan dalam pemakaian teknologi informasi. Sasaran dari TAM adalah untuk menyediakan sebuah penjelasan dari faktor-faktor penentu penerimaan komputer yang umum. TAM kurang umum dibandingkan dengan TRA. TAM didesain hanya untuk perilaku penggunaan komputer, namun karena menggabungkan berbagai temuan yang diakumulasi dari risetriset dalam beberapa dekade, maka TAM sesuai sebagai modelling penerimaan komputer.

Tujuan inti dari TAM adalah untuk menyediakan sebuah gambaran yang mendasari pengaruh faktor-faktor ekstenal terhadap kepercayaan (belief) internal, sikap dan tujuan. TAM diformulasikan dalam usaha untuk mencapai tujuantujuan tersebut dengan mengidentifikasi variabel-variabel yang mendasar seperti 
yang disarankan oleh riset-riset sebelumnya yang menyalurkan faktor kognitif dan afektif dari penerimaan komputer dan menggunakan TRA sebagai dasar teoritis untuk model hubungan teoritis diantara variabel-variabel tersebut. TRA digunakan sebagai dasar teoritis untuk menentukan hubungan sebab akibat antara dua kunci belief, yaitu (1) persepsi kegunaan, dan (2) persepsi kemudahan dari penggunaan terhadap sikap user dan tujuan perilaku adopsi komputer sesungguhnya. Kedua kunci belief tersebut relevan untuk perilaku penerimaan komputer (Kurniawan, 2013).

Hubungan grand theory ini dengan topik penelitian menyatakan bahwa sistem informasi akuntansi tidak bisa berfungsi jika tidak di dukung oleh sumber daya manusia. Sumber daya manusia merupakan aset tertinggi untuk meningkatkan kegiatan yang dilaksanakan dalam perusahaan. Karyawan merupakan penggerak utama kelancaran usaha dan kinerja perusahaan, karena itu karyawan harus memiliki keahlian pada bidang pekerjaannya. Keberhasilan perusahaan dalam mencapai sebuah tujuan dan memenuhi kebutuhan masyarakat sangat bergantung pada kinerja karyawan. Menyediakan laporan keuangan yang relevan dan reliabel yang dapat digunakan sebagai informasi dan dasar untuk pengambilan keputusan adalah upaya peningkatan kinerja individual dalam sudut pandang akuntansi. Kinerja individu adalah kemampuan individu untuk menyelesaikan suatu pekerjaan dengan berhasil dan efisien pada suatu perusahaan. Kinerja yang baik dapat terlihat apabila individu dapat menyelesaikan dan melaksanakan tugasnya dengan baik. Individu diharapkan dapat menyelesaikan pekerjaannya dengan bantuan teknologi, sehingga tugas yang dikerjakan dapat diselesaikan (Alannita \& Suaryana, 2014). Kinerja lebih tinggi berarti terjadi peningkatan kualitas yang baik dari kinerja individu, sehingga tugas yang akan diberikan kepada individu dalam suatu organisasi dapat dilaksanakan dengan tepat waktu (Murty \& Hudiwinarsih, 2012). Amelia \& Puspitawati, (2011) menyatakan bahwa teknologi informasi dapat dimanfaatkan secara efektif sehingga dapat memberikan kontribusi terhadap kinerja individual. Kinerja bergantung pada kombinasi antara kemampuan, usaha, dan kesempatan yang diperoleh.

Kemampuan teknik pemakai sistem informasi akuntansi banyak memberikan dampak positif bagi perusahaan dan dunia bisnis. Penerapan suatu sistem memberikan dua dampak bagi perusahaan yaitu keberhasilan sistem dan kegagalan sistem. Baik buruknya kinerja dari sebuah sistem informasi dapat dilihat dari kepuasan pemakai sistem informasi akuntansi tersebut. Para pemakai menjadi fokus yang penting dalam penerapan sebuah sistem dalam perusahaan. Pemakai atau pengguna merupakan suatu hal yang tidak terlepas dari penerapan teknologi, selain itu keberadaan manusia sangat berperan penting dalam penerapan teknologi. Ariyanto, (2013) menyatakan bahwa penggunaan teknologi sistem informasi yang tepat didukung oleh keahlian personel untuk mengoperasikan dan dapat meningkatkan kinerja perusahaan maupun kinerja individual pada perusahaan.

\section{METODE PENELITIAN}

Penelitian ini dilakukan pada koperasi simpan pinjam di Kecamatan Badung yang telah menerapkan sistem informasi akuntansi untuk mengolah data 
akuntansinya yang tercatat di Dinas Koperasi dan Usaha Mikro Kecil dan Menengah (UMKM) Kabupaten Badung. Lokasi tersebut dipilih karena Kecamatan di Kabupaten Badung memiliki jumlah koperasi simpan pinjam yang paling banyak dan aset koperasi simpan pinjam di Kabupaten Badung juga selalu meningkat setiap tahunnya.

Populasi dalam penelitian ini adalah karyawan pemakai sistem informasi akuntansi di koperasi simpan pinjam di Kabupaten Badung. Kabupaten Badung memiliki 78 koperasi simpan pinjam. Dari 78 koperasi ini hanya 53 koperasi yang telah menerapkan Sistem Informasi Akuntansi (SIA). Dengan demikian populasi dari penelitian ini adalah karyawan pemakai Sistem Informasi Akuntansi (SIA) pada 53 koperasi di Kabupaten Badung yang telah menggunakan Sistem Informasi Akuntansi (SIA) tersebut. Sehingga 53 Koperasi yang memenuhi syarat tersebut dijadikan potensi penelitian. Dengan demikian potensi penelitian dilihat dari koperasinya berjumlah 53 Koperasi.

Kriteria dalam pengambilan sampel dalam penelitian ini yaitu karyawan pemakai sistem informasi akuntansi di koperasi simpan pinjam di Kabupaten Badung yang telah bekerja lebih dari satu tahun. Masing-masing koperasi diambil 3 orang yang terdiri dari manajer, bagian pembukuan dan kasir koperasi sehingga jumlah sampel adalah jumlah sampel $=53$ koperasi $\times 3$ orang $=159$ orang.

Analisis regresi dipakai secara luas untuk melakukan prediksi dan ramalan. Analisis ini juga digunakan untuk memahami variabel bebas mana saja yang berhubungan dengan variabel terikat dan untuk mengetahui bentukbentuk hubungan tersebut. Dalam penelitian ini digunakan dua buah model analisis regresi, yaitu analisis regresi Moderated Regression Analysis (MRA).

\section{HASIL DAN PEMBAHASAN}

Jumlah keseluruhan responden adalah sebanyak 159 orang. Perbandingan antara pria dan wanita cukup terlampau jauh, di mana jumlah responden laki-laki lebih banyak dibandingkan dengan responden perempuan, yaitu responden laki-laki sebanyak 70 orang atau $49,65 \%$ dan responden perempuan sebanyak 89 orang atau $63,12 \%$. Hal ini menunjukkan bahwa jumlah responden dalam penelitian ini dengan jenis kelamin laki-laki lebih banyak daripada jumlah responden dengan jenis kelamin perempuan.

Karateristik responden berdasarkan umur dengan nilai paling banyak pada rentan umur antara 31-35 tahun dengan jumlah 73 orang atau 51,77\%, kemudian disusul dengan rentan umur antara 26-30 tahun dengan jumlah 32 orang atau 22,70\%. Selanjutnya disusul dengan rentan umur antara 36-40 tahun dengan total 31 orang atau 21,99\% dan disusul dengan rentan umur antara 21-25 tahun dengan total 12 orang atau 8,51\%. Dan yang memiliki nilai paling sedikit berada pada rentan umur lebih dari 40 tahun sebanyak 11 orang atau 7,80\%. Berdasarkan hal tersebut dapat dikatakan bahwa dari total 159 responden, mayoritas responden dalam penelitian ini memiliki umur antara 31-35 tahun dengan jumlah 73 orang atau $51,77 \%$.

Karateristik responden berdasarkan pendidikan terakhir dengan nilai paling banyak Strata-1 (S1) dengan jumlah 81 orang atau 57,45\%. Kemudian disusul dengan pendidikan terakhir Akademi (D3) dengan jumlah 55 orang atau 
39,01\%. Selanjutnya disusul dengan pendidikan terakhir SLTA dengan jumlah 13 orang atau $9,22 \%$ dan dengan jumlah pendidikan terakhir terendah adalah Strata-2 (S2) sebanyak 10 orang atau 7,09\%. Berdasarkan hal tersebut dapat dikatakan bahwa dalam penelitian ini dari 141 responden mayoritas berpendidikan terakhir Strata-1 (S1) dengan jumlah 81 orang atau 57,45\%.

Karateristik responden berdasarkan lama bekerja dengan nilai paling tinggi berada pada rentan waktu antara 3-4 tahun dengan jumlah 80 orang atau $56,74 \%$, kemudian disusul dengan rentan waktu antara 1-3 tahun dengan jumlah 32 orang atau 22,70\%. Selanjutnya, disusul dengan rentan waktu antara 5-6 tahun dengan jumlah 31 orang atau 21,99\% dan lebih dari 6 tahun sebanyak 9 orang atau $6,38 \%$. Kemudian dengan jumlah paling rendah pada lama bekerja kurang dari 1 tahun yaitu sebanyak 7 orang atau 4,96\%. Berdasarkan hal tersebut dapat dikatakan bahwa dari 141 responden dalam penelitian ini mayoritas sudah bekerja antara 3-4 tahun dengan jumlah 80 orang atau 56,74\%.

Hasil uji validitas variabel kemampuan teknik pemakai $\left(X_{1}\right)$ dengan bantuan program SPSS ver 21 for windows dapat di uraikan sebagai berikut.

Tabel 1. Uji Validitas Variabel Kemampuan Teknik Pemakai $\left(X_{1}\right)$

\begin{tabular}{ccccc}
\hline No & Indikator & r hitung & Kriteria & Validitas \\
\hline 1 & X1.1 & 0,776 & 0,30 & Valid \\
2 & X1.2 & 0,642 & 0,30 & Valid \\
3 & $X 1.3$ & 0,726 & 0,30 & Valid \\
\hline
\end{tabular}

Sumber: Data Penelitian, 2019

Berdasarkan Tabel 1 terlihat bahwa indikator dari variabel kemampuan

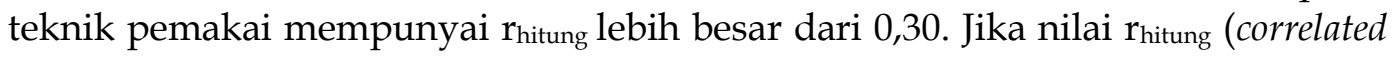
item-total correlation) lebih besar dari 0,30 maka butir atau pertanyaan tersebut dinyatakan valid.

Hasil uji validitas variabel efektivitas Sistem Informasi Akuntansi $\left(\mathrm{X}_{2}\right)$ dengan bantuan program SPSS ver 21 for windows dapat di uraikan sebagai berikut.

Tabel 2. Uji Validitas Variabel Efektivitas Sistem Informasi Akuntansi $\left(\mathrm{X}_{2}\right)$

\begin{tabular}{ccccc}
\hline No & Indikator & rhitung & Kriteria & Validitas \\
\hline 1 & X2.1 & 0,390 & 0,30 & Valid \\
2 & X2.2 & 0,391 & 0,30 & Valid \\
3 & X2.3 & 0,639 & 0,30 & Valid \\
4 & X2.4 & 0,504 & 0,30 & Valid \\
5 & X2.5 & 0,662 & 0,30 & Valid \\
6 & X2.6 & 0,555 & 0,30 & Valid \\
7 & X2.7 & 0,558 & 0,30 & Valid \\
8 & X2.8 & 0,470 & 0,30 & Valid \\
\hline
\end{tabular}

Sumber: Data Penelitian, 2019

Berdasarkan Tabel 2 terlihat bahwa indikator dari variabel kemampuan teknik pemakai mempunyai $\mathrm{r}_{\text {hitung }}$ lebih besar dari 0,30. Jika nilai $\mathrm{r}_{\text {hitung }}$ (correlated item-total correlation) lebih besar dari 0,30 maka butir atau pertanyaan tersebut dinyatakan valid.

Hasil uji validitas variabel kinerja individual (Y) dengan bantuan program SPSS ver 21 for windows dapat di uraikan sebagai berikut. 
Tabel 3. Uji Validitas Variabel Kinerja Individual (Y)

\begin{tabular}{ccccc}
\hline No & Indikator & rhitung & Kriteria & Validitas \\
\hline 1 & Y1 & 0,513 & 0,30 & Valid \\
2 & Y2 & 0,441 & 0,30 & Valid \\
3 & Y3 & 0,602 & 0,30 & Valid \\
4 & Y4 & 0,603 & 0,30 & Valid \\
5 & Y5 & 0,653 & 0,30 & Valid \\
6 & Y6 & 0,480 & 0,30 & Valid \\
\hline
\end{tabular}

Sumber: Data Penelitian, 2019

Berdasarkan Tabel 3 terlihat bahwa indikator dari variabel kemampuan teknik pemakai mempunyai $\mathbf{r}_{\text {hitung }}$ lebih besar dari 0,30. Jika nilai $\mathbf{r}_{\text {hitung }}$ (correlated item-total correlation) lebih besar dari 0,30 maka butir atau pertanyaan tersebut dinyatakan valid.

Uji realibilitas variabel kemampuan teknik pemakai $\left(X_{1}\right)$, efektivitas Sistem Informasi Akuntansi $\left(\mathrm{X}_{2}\right)$ dan kinerja individual $(\mathrm{Y})$ dengan menggunakan SPSS ver 21 for windows terlihat hasil seperti Tabel 4 sebagai berikut.

Tabel 4. Uji Reliabilitas Variabel Kemampuan Teknik Pemakai $\left(X_{1}\right)$, Efektivitas Sistem Informasi Akuntansi $\left(X_{2}\right)$ dan Kinerja Individual (Y)

\begin{tabular}{clccc}
\hline No. & \multicolumn{1}{c}{ Aspek Variabel } & $\begin{array}{c}\text { Cronbach's } \\
\text { Alpha }\end{array}$ & $\begin{array}{c}\text { Nilai } \\
\text { Kritis/ } \\
\text { Standard }\end{array}$ & Reliabilitas \\
\hline 1 & $\begin{array}{l}\text { Kemampuan Teknik Pemakai } \\
\left(\mathrm{X}_{1}\right)\end{array}$ & 0,826 & & Reliabel \\
2 & $\begin{array}{l}\text { Efektivitas Sistem Informasi } \\
\text { Akuntansi }\left(\mathrm{X}_{2}\right)\end{array}$ & 0,618 & $>0,6$ & \\
3 & Kinerja Individu $(\mathrm{Y})$ & 0,635 & & \\
\hline
\end{tabular}

Sumber: Data Penelitian, 2019

Berdasarkan ringkasan hasil uji reliabilitas seperti yang terangkum dalam Tabel 4 dapat diketahui bahwa nilai koefisien Cronbach Alpha pada variabel kemampuan teknik pemakai $\left(X_{1}\right)$, efektivitas Sistem Informasi Akuntansi $\left(X_{2}\right)$ dan kinerja individual $(\mathrm{Y})$ nilainya lebih besar dari nilai kritis/standard sebesar 0,6, maka dapat dikatakan bahwa semua butir pertanyaan dalam variabel penelitian ini adalah reliabel. Menurut kriteria Nunally dalam Ghozali, (2016) hal tersebut dapat dikatakan reliabel, sehingga butir-butir pertanyaan dalam variabel penelitian dapat digunakan untuk penelitian selanjutnya.

Uji normalitas bertujuan untuk menguji apakah dalam model regresi, variabel, pengganggu atau residual memiliki distribusi normal. Untuk menguji normalitas dalam penelitian ini peneliti menggunakan uji statistik dengan parametrik Kolmogrorov-Smirnow test (K-S) dengan menggunakan bantuan Program SPSS ver 15 for windows, hasil olah data terlihat seperti Tabel 5 berikut. 
Tabel 5. Hasil Normalitas dengan Kolmogrorov-Smirnow Test (K-S)

\begin{tabular}{llr}
\hline & & $\begin{array}{c}\text { Unstandardized } \\
\text { Residual }\end{array}$ \\
\hline $\mathrm{N}$ Normal Parameters(a,b) & & 159 \\
& Mean & .0000000 \\
Most Extreme Differences & Std. Deviation & .24875405 \\
& Absolute & .116 \\
& Positive & .116 \\
Kolmogorov-Smirnov Z & Negative & -.098 \\
Asymp. Sig. (2-tailed) & & 1.456 \\
& & .629 \\
\hline
\end{tabular}

Sumber: Data Penelitian, 2019

Tabel 5 menunjukkan besarnya nilai Kolmogorov-Smimov adalah 1,456 dan menunjukkan keadaan yang tidak signifikan dengan nilai derajat probabilitas signifikansi sebesar 0,629 atau $p$ value $>0,05$ atau 5\%. Hal ini berarti Ho diterima, yang artinya bahwa data residual berdistribusi normal atau dapat dikatakan telah lolos uji normalitas.

Uji heterokedastisitas bertujuan menguji apakah dalam model regresi terjadi ketidaksamaan varian dari residual suatu pengamatan ke pengamatan yang lain. Jika variance dari residual satu pengamatan ke pengamatan yang lain tetap, maka disebut homokedastisitas dan jika berbeda disebut heterokedastisitas. Selanjutnya uji heterokedastisitas dengan menggunakan Glejser dilakukan dengan menggunakan bantuan Program SPSS ver 15 for windows, hasil olah data terlihat seperti tabel 6 berikut.

Tabel 6. Hasil Uji Heterokedastisitas dengan Glejser

\begin{tabular}{|c|c|c|c|c|c|c|}
\hline \multirow{2}{*}{\multicolumn{2}{|c|}{ Model }} & \multicolumn{2}{|c|}{$\begin{array}{l}\text { Unstandardized } \\
\text { Coefficients }\end{array}$} & \multirow{2}{*}{$\begin{array}{c}\begin{array}{c}\text { Standardized } \\
\text { Coefficients }\end{array} \\
\text { Beta }\end{array}$} & \multirow[b]{2}{*}{$\mathrm{T}$} & \multirow[b]{2}{*}{ Sig. } \\
\hline & & $\mathrm{B}$ & Std. Error & & & \\
\hline 1 & (Constant) & 2,163 & ,672 & & 2,863 & , 000 \\
\hline & $\begin{array}{l}\text { Kemampuan Teknik } \\
\text { Pemakai (X1) }\end{array}$ & 211 & 612 & 1,007 & ,216 & ,217 \\
\hline & Efektivitas Sistem & & & & & \\
\hline & $\begin{array}{l}\text { Informasi Akuntansi } \\
(\mathrm{X} 2)\end{array}$ & 3,361 & 261 & 826 & ,297 & 871 \\
\hline & $\mathrm{X} 1 \mathrm{X} 2$ & ,007 & ,023 & 1,428 & ,286 & 198 \\
\hline
\end{tabular}

Sumber: Data Penelitian, 2019

Tabel 6 menunjukkan bahwa tidak ada satupun variabel independen yang signifikan secara statistik mempengaruhi variabel dependen nilai absolut $Y$ atau | Y | . Hal ini terlihat dari probabilitas signifikansinya atau $p$ value-nya masing-masing di atas 0,05 atau di atas tingkat kepercayaan 5\%, jadi dapat disimpulkan model regresi tidak mengandung adanya heterokedastisitas.

Variabel dari penelitian ini terdiri dari kemampuan teknik pemakai, efektivitas Sistem Informasi Akuntansi dan kinerja individu. Statistik deskriptif dari variabel penelitian dapat disajikan dalam Tabel 7 berikut: 
Tabel 7. Hasil Analisis Statistik Deskriptif

\begin{tabular}{|c|c|c|c|c|c|}
\hline & $N$ & Minimum & Maximum & Mean & Std.Deviation \\
\hline $\begin{array}{l}\text { Kemampuan.Teknik. } \\
\text { Pemakai.(X1) }\end{array}$ & 159 & 5,00 & 12,00 & 10,0063 & 1,89435 \\
\hline Efektivitas.Sistem. & 159 & 14,00 & 32,00 & 26,6981 & 3,52164 \\
\hline Informasi.Akuntansi.(X2) & 159 & & & & \\
\hline $\begin{array}{l}\text { Kinerja.Individu.(Y) } \\
\text { Valid N (listwise) }\end{array}$ & 159 & 12,00 & 24,00 & 20,0818 & 2,71183 \\
\hline
\end{tabular}

Sumber: Data Penelitian, 2019

Nilai minimum kemampuan teknik pemakai $\left(X_{1}\right)$ adalah 5,00 dan nilai maksimumnya sebesar 12,00 . Mean rata-rata kemampuan teknik pemakai $\left(X_{1}\right)$ sebesar 10,00 artinya bahwa rata-rata kemampuan teknik pemakai $\left(\mathrm{X}_{1}\right)$ sebesar 10,00 dengan nilai standard deviasi sebesar 1,89 yang berarti penyimpangan kemampuan teknik pemakai $\left(X_{1}\right)$ yang diteliti terhadap rata-ratanya sebesar 1,89 .

Nilai minimum efektivitas Sistem Informasi Akuntansi $\left(X_{2}\right)$ adalah 14,00 dan nilai maksimumnya sebesar 32,00. Mean rata-rata efektivitas Sistem Informasi Akuntansi $\left(X_{2}\right)$ sebesar 26,69 artinya bahwa rata-rata efektivitas Sistem Informasi Akuntansi $\left(X_{2}\right)$ sebesar 26,69 dengan nilai standard deviasi sebesar 3,52 yang berarti penyimpangan efektivitas Sistem Informasi Akuntansi $\left(\mathrm{X}_{2}\right)$ yang diteliti terhadap rata-ratanya sebesar 3,52.

Nilai minimum kinerja individu (Y) adalah 12,00 dan nilai maksimumnya sebesar 24,00. Mean rata-rata kinerja individu (Y) sebesar 20,08 artinya bahwa rata-rata kinerja individu $(\mathrm{Y})$ sebesar sebesar 20,08 dengan nilai standard deviasi sebesar 2,71 yang berarti penyimpangan kinerja individu (Y) yang diteliti terhadap rata-ratanya sebesar 2,71. Dari hasil analisis regresi sederhana $X_{1}$ terhadap Y, didapat hasil sebagai berikut :

Tabel 8. Hasil Analisis Regresi

\begin{tabular}{|c|c|c|c|c|c|c|}
\hline & \multicolumn{2}{|c|}{$\begin{array}{l}\text { Unstandardized } \\
\text { Coefficients }\end{array}$} & \multirow{2}{*}{$\begin{array}{c}\begin{array}{c}\text { Standardized } \\
\text { Coefficients }\end{array} \\
\text { Beta }\end{array}$} & \multirow[b]{2}{*}{$\mathrm{T}$} & \multirow[b]{2}{*}{ Sig. } \\
\hline & & $\mathrm{B}$ & Std. Error & & & \\
\hline 1 & (Constant) & 2,565 & 183 & דר & 1,995 & 000 \\
\hline
\end{tabular}

Sumber: Data Penelitian, 2019 berikut:

Berdasarkan Tabel 8, maka persamaan regresi yang di dapat adalah sebagai

Keterangan:

$$
Y=2,565+0,234 X_{1}
$$

$\mathrm{Y}=$ Kinerja Individu

$\mathrm{X}_{1}=$ Kemampuan Teknik Pemakai

Berdasarkan persamaan di atas dapat dilakukan interpretasi bahwa koefisien regresi $b 1=2,565$ mempunyai arti bahwa peningkatan kemampuan teknik pemakai $\left(\mathrm{X}_{1}\right)$ sebesar $1 \%$ akan menaikkan kinerja individu $(\mathrm{Y})$ sebesar 2,565 (faktor lain dianggap tetap). Persamaan model matematis di atas menunjukkan bahwa kemampuan teknik pemakai memiliki pengaruh positif terhadap kinerja individu. Hal itu ditunjukkan dari koefisien regresi kemampuan teknik pemakai yaitu positif 0,234 . 
Untuk mengukur seberapa jauh kemampuan variabel bebas dalam menerangkan variabel yang terikat digunakan koefisien determinasi, dari nilai $\mathrm{R}^{2}$. Kelemahan mendasar penggunaan koefisien determinasi adalah bias terhadap jumlah variabel independen yang dimasukkan ke dalam model. Oleh karena itu banyak peneliti menganjurkan untuk menggunakan nilai Adjusted $\mathrm{R}^{2}$ pada saat mengevaluasi model regresi yang terbaik. Hasil olah data SPSS ditunjukkan pada tabel berikut ini:

Tabel 9. Model Summary

\begin{tabular}{crrrr}
\hline & & & Adjusted & \multicolumn{2}{c}{$\begin{array}{l}\text { Std. Error of } \\
\text { the Estimate }\end{array}$} \\
\hline 1 & $\mathrm{R}$ & R Square & R Square & the \\
\hline
\end{tabular}

Sumber: Data Penelitian, 2019

Berdasarkan tampilan output SPSS model summary atau Tabel 9 tersebut di atas, besarnya Adjusted $\mathrm{R}^{2}$ adalah 0,396 hal ini berarti 29,6\% variabel dependen kinerja individu (Y) dapat dijelaskan atau dipengaruhi oleh variabel independen kemampuan teknik pemakai $\left(X_{1}\right)$, sedangkan sisanya 70,4\% (100\%-29,6\%) dijelaskan atau dipengaruhi oleh variable-variabel lain di luar model penelitian seperti misalnya motivasi kerja, tingkat gaji, kepemimpinan, budaya organisasi dan sebagainya.

Berdasarkan hasil uji analisis Moderated Regression Analysis (MRA) dengan bantuan SPSS diperoleh hasil sebagai berikut:

Tabel 10. Hasil Analisis Moderated Regression Analysis (MRA)

\begin{tabular}{llrrrrr}
\hline & \multicolumn{5}{c}{ Unstandardized } & \multicolumn{3}{c}{$\begin{array}{c}\text { Standardized } \\
\text { Coefficients }\end{array}$} & & \\
\cline { 3 - 5 } & & \multicolumn{1}{c}{ Coefficients } & \multicolumn{1}{c}{ Std. Error } & Beta & \multicolumn{1}{c}{ Sig. } \\
\hline 1 & (Constant) & $-1,327$ & 1,224 & & $-1,085$ &, 280 \\
& X1 &, 441 &, 117 &, 376 & 3,767 &, 000 \\
X2 &, 369 &, 044 &, 583 & 8,425 &, 000 \\
X1X2 &, 009 &, 004 &, 272 & 2,225 &, 028 \\
\hline
\end{tabular}

Sumber: Data Penelitian, 2019

Berdasarkan Tabel 10, maka persamaan Moderated Regression Analysis (MRA) yang di dapat adalah sebagai berikut:

Dimana :

$$
Y=-1,327+0,441 X_{1}+0,369 X_{2}+0,009 X_{1}, X_{2}
$$

$$
\begin{array}{ll}
\mathrm{Y} & =\text { kinerja individual } \\
\mathrm{X}_{1} & =\text { kemampuan teknik pemakai } \\
\mathrm{X}_{2} & =\text { efektivitas Sistem Informasi Akuntansi } \\
\mathrm{a}, \beta_{0} & =\text { konstanta } \\
\beta_{1}, \beta_{2}, \beta_{3} & =\text { koefisien regresi } \\
\mathrm{e} & =\text { standar error }
\end{array}
$$

Berdasarkan persamaan di atas dapat dilakukan interpretasi bahwa nilai konstanta sebesar -1,327 memiliki tanda negatif yang berarti jika kemampuan teknik pemakai sama dengan 0 . maka kinerja individu adalah cenderung negatif yang berarti kinerjanya individunya tidak bagus. Nilai koefisien kemampuan teknik pemakai beta 0,441 memiliki tanda positif yang berarti bahwa semakin baik kemampuan teknik pemakai maka kinerja individualnya cenderung meningkat. Nilai koefisien interaksi kemampuan teknik pemakai dengan 
efektivitas memiliki koefisien beta 0,09 yang mengindikasi bahwa pengaruh kemampuan teknik pemakai akan menyebabkan kinerja individual semakin meningkat saat efektivitas sistem informasi semakin baik. Hasil olah data SPSS ditunjukkan pada tabel 11.

Tabel 11. Model Summaryb

\begin{tabular}{rrrrrr}
\hline Model & $\mathrm{R}$ & R Square & $\begin{array}{l}\text { Adjusted } \\
\text { R Square }\end{array}$ & $\begin{array}{l}\text { Std. Error of } \\
\text { the Estimate }\end{array}$ \\
\hline 1 & &, $965^{\mathrm{a}}$ &, 932 &, 931 &, 65634 \\
\hline
\end{tabular}

Sumber: Data Penelitian, 2019

Berdasarkan tampilan output SPSS model summary atau Tabel 11 besarnya Adjusted $\mathrm{R}^{2}$ adalah 0,931 hal ini berarti 93,1\% variabel dependen kinerja individu (Y) dapat dijelaskan atau dipengaruhi oleh variabel kemampuan teknik pemakai $\left(X_{1}\right)$ dan interaksi variabel kemampuan teknik pemakai $\left(X_{1}\right)$ dengan efektivitas Sistem Informasi Akuntansi $\left(X_{2}\right)$, sedangkan sisanya 6,9\% (100\%-93,1\%) dijelaskan atau dipengaruhi oleh variable-variabel lain di luar model penelitian.

Hasil kelayakan model (F) dapat dilihat dari nilai F dan signifikansi F dari tabel output SPSS berikut ini:

Tabel 12. Uji Kelayakan Model (F)

\begin{tabular}{lrrrrr}
\hline & Sum of & & & & \\
Model & Squares & $d f$ & Mean Square & \multicolumn{1}{c}{ Sig. } \\
\hline 1 & 808,784 & 3 & 269,595 & 625,818 &, $000^{\text {a }}$ \\
Regression & 59,018 & 137 &, 431 & & \\
$\quad$ Residual & 867,801 & 140 & & & \\
$\quad$ Total & & & & & \\
\hline
\end{tabular}

Sumber: Data Penelitian, 2019

Dari tabel 12 terlihat bahwa nilai signifikansi $\mathrm{F}$ atau sig sebesar 0,000< 0,05 (5\%). Kondisi ini menunjukkan variabel bebas yang digunakan dalam penelitian ini yaitu kemampuan teknik pemakai dan efektivitas sistem informasi akuntansi berpengaruh secara serempak pada kinerja individual. Dengan demikian, pembuktian hipotesis dapat dilanjutkan.

Hasil uji signifikansi parsial (uji-t) dengan menggunakan Program SPSS ver 21 for windows dapat dilihat pada Tabel 8. Berdasarkan Tabel 8 tersebut dapat dilihat bahwa nilai probabilitas signifikansi atau sig.-nya adalah 0,000 atau lebih kecil dari 0,05 atau 5\%. Selain itu Tabel 8 juga menunjukkan koefisien regresi positif 0,234 , sehingga hipotesis yang menyatakan kemampuan teknik pemakai berpengaruh positif pada kinerja individual pada Koperasi Simpan Pinjam di Kabupaten Badung dinyatakan diterima.

Hasil uji Moderated Regression Analysis (MRA) dengan menggunakan Program SPSS ver 21 for windows dapat dilihat pada Tabel 10 Berdasarkan Tabel 10 tersebut, dapat dilihat bahwa nilai probabilitas signifikansi atau sig.-nya adalah 0,028 atau lebih kecil dari 0,05 atau 5\%. Selain itu juga didapat nilai koefisien regresi interaksi antara kemampuan teknik pemakai $\left(\mathrm{X}_{1}\right)$ dengan efektivitas sistem informasi akuntansi $\left(X_{2}\right)$ sebesar 0,009. Hasil ini menunjukkan bahwa hipotesis yang menyatakan efektivitas Sistem Informasi Akuntansi mampu memoderasi pengaruh kemampuan teknik pemakai pada kinerja individual di Koperasi Simpan Pinjam di Kabupaten Badung. 
Hasil penelitian ini menerima hipotesis $\mathrm{H}_{1}$ yang menyatakan kemampuan teknik pemakai berpengaruh positif pada kinerja individual di Koperasi Simpan Pinjam di Kabupaten Badung. Pengaruh yang positif ini berarti terdapat hubungan yang searah antara kemampuan teknik pemakai dengan kinerja individual. Semakin tinggi tingkat kemampuan teknik pemakai, maka semakin tinggi kinerja individual. Koperasi simpan pinjam yang mampu mempunyai pegawai yang memiliki kemampuan teknik pemakai yang dapat memanfaatkan teknologi Sistem Informasi Akuntansi secara efektif maka akan mampu menghasilkan informasi yang dapat diterima secara tepat waktu, akurat, dan dapat dipercaya yang nantinya dapat meningkatkan kinerja individual koperasi simpan pinjam.

Hasil penelitian ini mendukung hasil penelitian Alannita \& Suaryana, (2014) yang menemukan bukti bahwa kemampuan teknik pemakai berpengaruh positif terhadap kinerja individu. Hasil penelitian ini juga sesuai dengan hasil penelitian Mahendra \& Widhiyani, (2016) yang menyimpulkan bahwa kemampuan pengoperasian sistem seorang pemakai sangat dibutuhkan. Penggunaan sistem informasi akuntansi dalam organisasi menuntut pemakai komputer (user) meningkatkan kemampuannya dalam menggunakan komputer. Pemakai yang mahir dan memahami sistem akan berpengaruh pada kinerja yang dihasilkan dari sistem tersebut.

Selain medukung kedua penelitian tersebut, hasil penelitian ini juga mendukung teori keyakinan diri seperti yang dikemukakan Bandura, (2010) yang menjelaskan proses kognitif sebagai salah satu proses keyakinan diri yang mempengaruhi fungsi manusia (Bandura, 2010). Proses tersebut meliputi kemampuan individu dalam menganalisis dan mengungkapkan ide. Kemampuan yang dimiliki oleh karyawan akan meningkatkan keyakinan diri yang mempengaruhi penggunaan sistem informasi.

Hasil penelitian ini menerima hipotesis $\mathrm{H}_{2}$ yang menyatakan efektivitas Sistem Informasi Akuntansi yang memoderasi kemampuan teknik pemakai pada pada kinerja individual di Koperasi Simpan Pinjam di Kabupaten Badung. Hasil penelitian ini mendukung hasil temuan penelitian Alannita \& Suaryana, (2014) serta hasil penelitian Widyasari \& Sadha Suardikha, (2015) yang menemukan kemampuan teknik pemakai Sistem Informasi Akutansi berpengaruh positif terhadap kinerja individual yang mampu meningkatkan efektivitas sistem informasi akutansi.

Hasil penelitian ini mendukung pendapat Setyawan, (2013) yang mengatakan pemakai Sistem Informasi Akuntansi dapat mendorong kinerja sistem informasi menjadi lebih baik. Kinerja sistem informasi berjalan dengan baik apabila para pemakai dapat memahami, menggunakan, dan mengaplikasikan sebuah teknologi menjadi sebuah informasi yang berguna untuk pengambilan keputusan sehingga tujuan perusahaan dapat terpenuhi dan kinerja individual dapat dinilai baik. Kemampuan teknik personal pemakai sistem informasi juga berperan penting dalam mengembangkan sistem informasi untuk dapat menghasilkan informasi guna menciptakan laporan perencanaan yang akurat, oleh karena itu setiap karyawan harus dapat menguasai penggunaan sistem berbasis komputer agar dapat memproses sejumlah transaksi dengan cepat dan terintegrasi, dapat menyimpan data dan mengambil data 
dalam jumlah yang besar, dapat mengurangi kesalahan matematik, menghasilkan laporan tepat waktu dalam berbagai bentuk, serta dapat menjadi alat bantu keputusan.

\section{SIMPULAN}

Kemampuan teknik pemakai mempunyai pengaruh positif pada kinerja individual di Koperasi Simpan Pinjam di Kabupaten Badung. Semakin tinggi kemampuan teknik pemakai, maka semakin tinggi kinerja individual. Besarnya pengaruh kemampuan teknik pemakai terhadap kinerja individual sebesar 29,6\% dan sisanya 70,4\% dipengaruhi oleh variabel-variabel lain di luar model seperti motivasi kerja, tingkat gaji, kepemimpinan, budaya organisasi dan sebagainya.

Efektivitas Sistem Informasi Akuntansi memoderasi pengaruh kemampuan teknik pemakai pada kinerja individual di Koperasi Simpan Pinjam di Kabupaten Badung. Semakin baik kemampuan teknik pemakai maka akan meningkatkan efektivitas Sistem Informasi Akuntansi sehingga kinerja individual akan meningkat.

Mengingat total nilai skor pada kuesioner kemampuan teknik pemakai Sistem Informasi Akuntansi yang paling rendah pada indikator yaitu kemampuan mengoperasikan SIA yang ada dan keahlian dalam menyelesaikan pekerjaan yang menjadi tanggungjawab karyawan yang keduanya bernilai total 467, maka disarankan agar kemampuan mengoperasikan SIA yang ada dan keahlian dalam menyelesaikan pekerjaan yang menjadi tanggungjawab karyawan segera ditingkatkan baik melalui pelatihan internal maupun pelatihan eksternal.

Mengingat total nilai skor pada kuesioner efektivitas Sistem Informasi Akuntansi yang paling rendah pada indikator yaitu SIA memberikan keuntungan dalam meningkatkan kinerja karyawan yang bernilai total 485, maka disarankan agar pemanfaatan SIA lebih ditingkatkan supaya dapat memberikan keuntungan dalam meningkatkan kinerja karyawan.

Mengingat total nilai skor pada kuesioner kinerja individual yang paling rendah pada indikator yaitu dukungan dari atasan dalam menyelesaikan perkerjaan menggunakan SIA yang bernilai total 359, maka disarankan dukungan dari atasan dalam menyelesaikan perkerjaan menggunakan SIA untuk ditingkatkan.

\section{REFERENSI}

Alannita, N. P., \& Suaryana, I. G. N. A. (2014). Pengaruh Kecanggihan Teknologi Informasi, Partisipasi manajemen, dan Kemampuan Teknik Pemakai Sistem Informasi Akuntansi pada Kinerja Individu. E-Jurnal Akuntansi Universitas Udayana, 6(1), 33-45.

Amelia, S., \& Puspitawati, L. (2011). Pengaruh Kemampuan Pengguna Terhadap Sistem Informasi Akuntansi dan Implikasinya pada Kualitas Informasi Akuntansi. Jurnal Universitas Komputer Indonesia Bandung, 7(2), 1-16.

Ariyanto, D. (2013). Pengaruh Efektivitas Penggunaan dan Kepercayaan Teknologi Sistem Informasi Terhadap Kinerja Individual. E- Jurnal Akuntansi Universitas Udayana, 2(1).

Bandura, A. (2010). Self Efficacy Mechanism in Psikological and HealthPromoting 
Behavior. New Jersey: Prentice Hall.

Davis, F. D. (1989). Perceived Usefulness, Perceived Ease of Use, and User Acceptance of Information Technology. MIS Quarterly, 13(3), 319-340. https://doi.org/10.2307/249008

Ghozali, I. (2016). Aplikasi Analisis Multivariete Dengan Program IBM SPSS 23 (8th ed.). Semarang: Badan Penerbit Universitas Diponegoro.

Grande, E. U. (2011). The Impact of Accounting Information System (AIS) on Performance Measures: Empirical Evidence in Spanish SMEs. The International Journal of Digital Accounting Research, 11(6), 25-43. https://doi.org/10.4192/1577-8517-v11

Gupta, H. (2011). Management System Information. New Delhi: International Book House.

Ismail, N. A., \& King, M. (2014). Journal of information systems and small business. Journal of Information Systems and Small Business, 1(1-2), 1-20. Retrieved from https://ojs.deakin.edu.au/index.php/jissb/article/view/1

Jogiyanto, H. (2012). Teori Portofolio dan Analisis Investasi (8th ed.). Yogyakarta: BPFE.

Kurniawan, A. (2013). Analisis Teknologi (TAM) dalam Penggunaan E-Banking. Skripsi. Sarjana Jurusan Akuntansi Universitas Katolik Soegijapranata Semarang.

Mahendra, I. G. A., \& Widhiyani, N. L. S. (2016). Kemampuan Teknik Pemakai Memoderasi Pengaruh Efektivitas Sistem Informasi Akuntansi pada Kinerja Individual Koperasi Simpan Pinjam. E-Jurnal Akuntansi Universitas Udayana, 15(3), 1886-1912.

Marlinawati, N. M. A., \& Suaryana, I. G. N. A. (2012). Pengaruh Penggunaan Teknologi Informasi, Efektivitas Sistem Informasi Akuntansi, Kepercayaan atas Sistem Informasi Akuntansi, dan Kesesuaian Tugas pada Kinerja Karyawan Lembaga Perkreditan Desa di Kabupaten Badung. E-Jurnal Akuntansi Universitas Udayana, 1(1), 388-401.

Murty, W. A., \& Hudiwinarsih, G. (2012). Pengaruh Kompensasi, Motivasi dan Komitmen Organisasional Terhadap Kinerja Karyawan Bagian Akuntansi. The Indonesian Accounting Review, 2(2), 215-228. https://doi.org/10.14414/tiar.v2i02.97

Nugroho, M. A. (2014). Model Penerimaan E-Commerce. Jurnal Pendidikan Akuntansi Indonesia, VII(2), 1-12.

Pratama, G. A., \& Suardikha, I. M. S. (2013). Keahlian Pemakai Komputer dan Kenyamanan Fisik dan Tingkat Efektivitas Sistem Informasi Akuntansi Terhadap Kinerja Karyawan. E-Jurnal Akuntansi Universitas Udyana, 5(2), 361-381.

Robbins, S., \& Judge, T. A. (2013). Organizational Behavior (15th ed.). New Jersey: Pearson Education.

Setyawan, H. (2013). Pengaruh Kualitas Informasi, Kemampuan Kemampuan Teknik Personal Sistem Informasi, Pelatihan Dan Pendidikan Pemakai Sistem Pelatihan Dan Pendidikan Pemakai Sistem Terhadap Kinerja Sistem Informasi. Skripsi.Sarjana Jurusan Akuntansi Fakultas Ekonomi Universitas Jember. Retrieved from http:/ / repository.unri.ac.id/handle/123456789/3446

Suartika, K. A., \& Widhiyani, N. L. S. (2017). Kemampuan Teknik Personal Pada 
Efektivitas Pendidikan Dan Pelatihan Sebagai Pemoderasi. E-Jurnal Akuntansi Universitas Udayana, 18(2), 1485-1512.

Susanto, A. (2013). Sistem Informasi Akuntansi, Struktur Pengendalian Risiko Pengembangan (Perdana). Bandung: Lingga Jaya.

Widyasari, H., \& Sadha Suardikha, I. (2015). Pengaruh Kemampuan Teknik Pemakai, Efektivitas Sia, Dukungan Manajemen Puncak, Lingkungan Kerja Fisik Pada Kinerja Individual. E-Jurnal Akuntansi Universitas Udayana, 11(3), 678-697.

Wijaya, A., \& Aliyanto, A. (2015). Analisis Penerimaan Google Apps For Education Dengan Menggunakan Model TAM ( Technology Acceptance Model ). Seminar Nasional Teknologi Informasi Dan Komunikasi (Semantik), 519524. 